\title{
Natural Stones Used in the Orsi-Marconi Palace Façade (Bologna): A Petro-Mineralogical Characterization
}

\author{
Elena Marrocchino ${ }^{1, *(\mathbb{D}}$, Chiara Telloli $^{2}{ }^{(0)}$, Martina Pedrini ${ }^{1}$ and Carmela Vaccaro ${ }^{1,2,3}(\mathbb{C}$ \\ 1 Department of Physics and Earth Sciences, University of Ferrara, 44121 Ferrara, Italy; \\ martina.pedrini@edu.unife.it (M.P.); vcr@unife.it (C.V.) \\ 2 Energy and Sustainable Economic Development Fusion and Technology for Nuclear Safety and Security \\ Department Nuclear Safety, Security and Sustainability Division, Italian National Agency for New \\ Technologies, ENEA, 40129 Bologna, Italy; chiara.telloli@enea.it \\ 3 ISAC-CNR Institute of Atmospheric Sciences and Climate of the National Research Council of Italy, 40129 \\ Bologna, Italy \\ * Correspondence: mrrlne@unife.it; Tel.: +39-33-9380-7477
}

Received: 31 July 2020; Accepted: 30 September 2020; Published: 7 October 2020

\begin{abstract}
Ancient buildings are important components of the Italian Cultural Heritage and, since the Etruscan Period, Bologna (north-eastern Italy) has always been one of the most flourishing cities both culturally and economically in the Italian and European panorama. The Orsi-Marconi Palace in Bologna presents a monumental façade decorated with many sandstone ornaments of the 16th century. Different samples from different parts of the façade of the building were collected and firstly characterised by macroscopic observations to determine the structural aspect. A petro-mineralogical study on the surfaces of the samples was conducted using a stereomicroscope and Optical Transmitted Light Polarized Microscopy. In addition, X-Ray Fluorescence and X-Ray Powder Diffractometer analyses were carried out to better understand the mineralogical composition of the sandstone materials used and the degradation products from the façades of this historical building. The aim of this work was to better understand how to revalue the sandstone decorations severely affected by deterioration phenomena.
\end{abstract}

Keywords: sandstones; petro-mineralogical analysis; atmospheric pollutants

\section{Introduction}

The Orsi-Marconi Palace is one of the most noteworthy architectures in Bologna city (Italy). It was realized by the famous architect Antonio Morandi, known with the nickname "Terribilia," in the middle of the 16th century and it is characterised by a monumental façade decorated with many sandstone ornaments. Orsi was one of the oldest and most illustrious families in Bologna, which played a leading role in political life since the 12th century and which lived continuously in the palace located in Via S. Vitale and is the object of this study.

At the beginning, the palace was divided into two different houses, until the architect Antonio Morandi planned the works for the unification of two houses into a single building, what later became Orsi Palace (1549-1564) [1,2], an emblematic building of the 16th century. Morandi worked on the façade of the palace building consisting of terracotta with elegant sandstone decorations. With the extinction of the Orsi family, the palace was bought by several aristocratic families of Bologna city, and in the early 20th century it become the residence of the family of the inventor and engineer Guglielmo Marconi, hence the current name Orsi-Marconi Palace. 
This paper describes a petro-mineralogical approach to characterise the historical construction building materials of the Orsi-Marconi Palace to better understand the quarry of origin of the sandstones used in the palace.

Orsi-Marconi Palace is located in the centre of the city of Bologna which in the last decades was affected by a high level of urban atmospheric pollutants, such as $\mathrm{CO} 2$ from traffic, sulphur, $\mathrm{PAH}$, (Polycyclic Aromatic Hydrocarbons) etc. [3-5]. Due to these anthropogenic pollutants, not only was the esthetical appearance seriously compromised, but structural damage was also caused [6,7]. In addition, the impact of anthropogenic factors increases the intensity of weathering and the subsequent formation of secondary minerals. These are primarily salts forming black crust and efflorescence either on the rock surfaces and accumulate in the subsurface layers [8-10].

The course of the damage of exposed rock or sandstone surfaces depends on both internal factors, such as mineral composition, structure and texture of the rock considered, and external ones, for instance, climate and anthropogenic pressure. Çelik and Kaçmaz [11] have shown that building deterioration is often caused by water from the ground rising up through the stone: As water evaporates, salts are left behind which crystallise at the surface. Damage can also be caused by the physical impact of ice forming and melting during cold weather [12-14]. Apart from the action of natural weathering parameters, such as rain, wind, temperature, or stresses due to freezing of water in the stone [15,16], environmental pollutants to which stone surfaces are exposed is the main factor that accelerates stone decay processes [17-19].

From literature, there were no known renovations to the façade of the Orsi-Marconi Palace, which probably, caused by atmospheric events, led to the deterioration of this splendid façade.

This work focuses on the chemical and mineralogical characterization of material collected from the restoration site of the Orsi-Marconi Palace façade aiming to implement the information on natural stone materials used for its decorative parts in order to revalue the sandstone decorations severely affected by deterioration.

The diagnosis of the conservation state of heritage buildings and building materials in general has been the aim of many works [20-23]. Due to all the factors mentioned above, an integrated analytical method is necessary for the identification of the sources of stone damage and the impact on the stone conservation of air pollution and meteoric water.

Different kind of samples from different parts of the Orsi-Marconi Palace façade were collected and analysed in the Department of Physics and Earth Sciences laboratories (Ferrara University). Macroscopic characterization on the surfaces of collected samples was carried out using a stereomicroscope and Optical Transmitted Light Polarized Microscopy (OTLPM) in order to determine their structural aspect. In addition, the chemical and mineralogical composition of the samples were characterised by X-Ray Fluorescence (XRF) analysis and X-Ray Powder Diffractometric (XRPD) analysis respectively to better define their mineralogical composition.

\section{Materials and Methods}

\subsection{Sampling}

The sampling was carried out on the façade of Orsi-Marconi Palace located in via San Vitale nn. 28-30 in the centre of Bologna city (Emilia Romagna region, north of Italy-Figure 1). The palace is located in one of the most polluted and busy areas in the centre of Bologna with a lot of traffic. For this reason, the façade of the palace was affected, in all its extension, by deterioration phenomena as for other important historical buildings in Italy [24,25] and in Europe [26,27].

Figure 2a shows an example of the black crusts observed that were visible in all the façade with different extensions and concentrations depending on the area and the material concerned [28-32]. Other degradation factors caused other types of damage on the façade, including fractures (Figure 2b) and sandstone exfoliation (Figure 2c). 


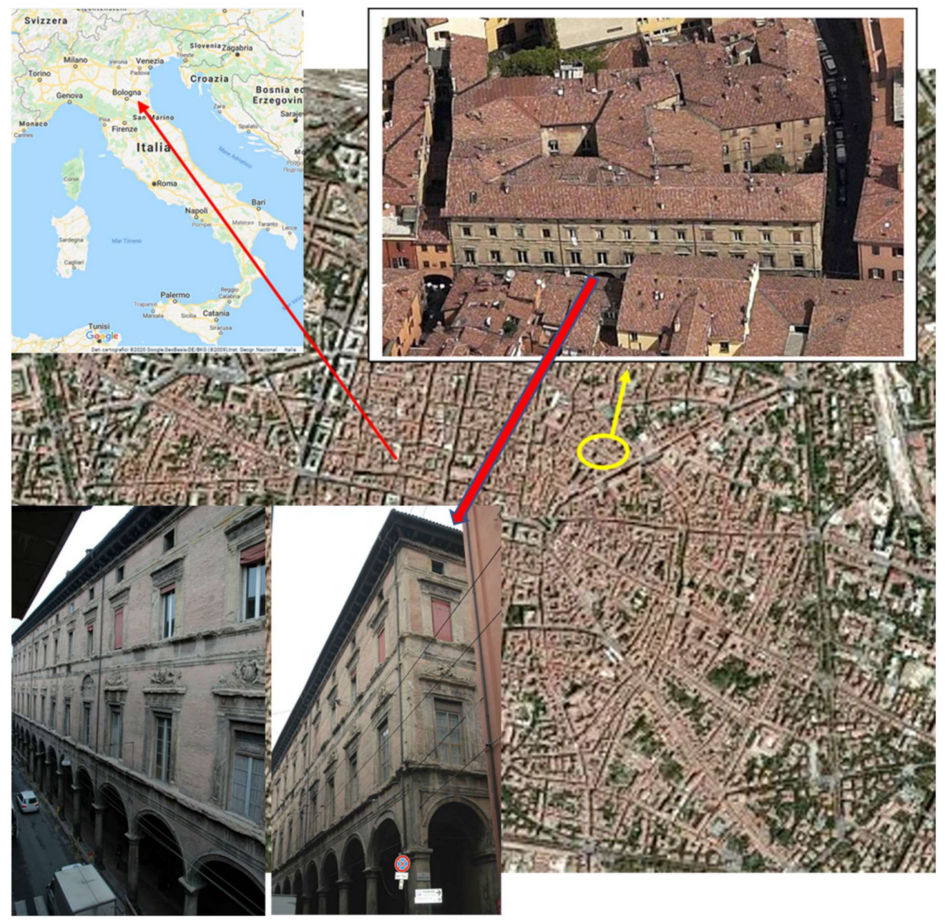

Figure 1. Sampling site in the city centre of Bologna (Emilia Romagna region in the north of Italy). On the top, enlargement of the Orsi-Marconi façade located in via San Vitale in Bologna.
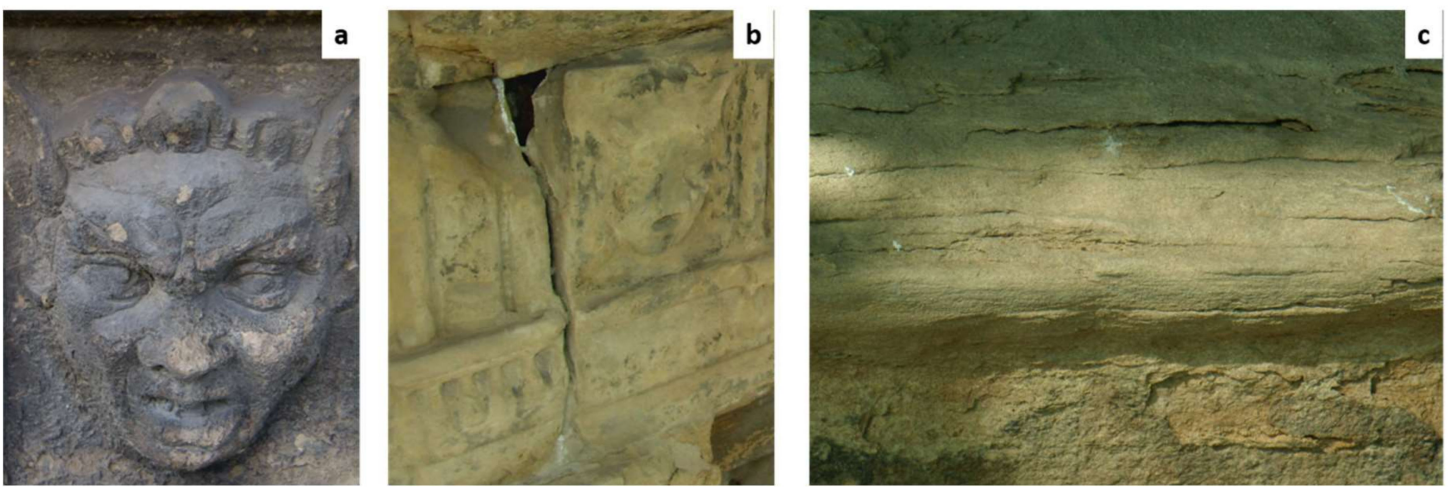

Figure 2. Examples of degradation phenomena on the façade of the Orsi-Marconi Palace: (a) black crust; (b) fractures; (c) exfoliations.

In addition to the brick that makes up the stonework, the façade is adorned with numerous sandstone architectural elements, a construction material frequently used in the city of Bologna in the past as for other important historical buildings in Italy [24,28].

The poor state of conservation of the building was visible through a lot of black crust at medium and high levels, with exfoliation and detachments (all the brown part of the building in Figure $3 b$ ). The black crusts represent the majority part of the deterioration of the façade of the building (about 70\%). Other visible deterioration elements were characterized by exfoliation and detachments (represented by the yellow part in Figure 3b) about 20\%. Minor deteriorations were represented by lack of materials (blue part in Figure 3b), cracks, alveolizations, wind-rain erosion, and bird's guano.

In order not to further compromise the state of conservation of the building, samples were collected on material already removed or on areas without decorations. Figure 3 shows the specific place in which different kinds of samples were collected on the Orsi-Marconi Palace façade to be analysed. 

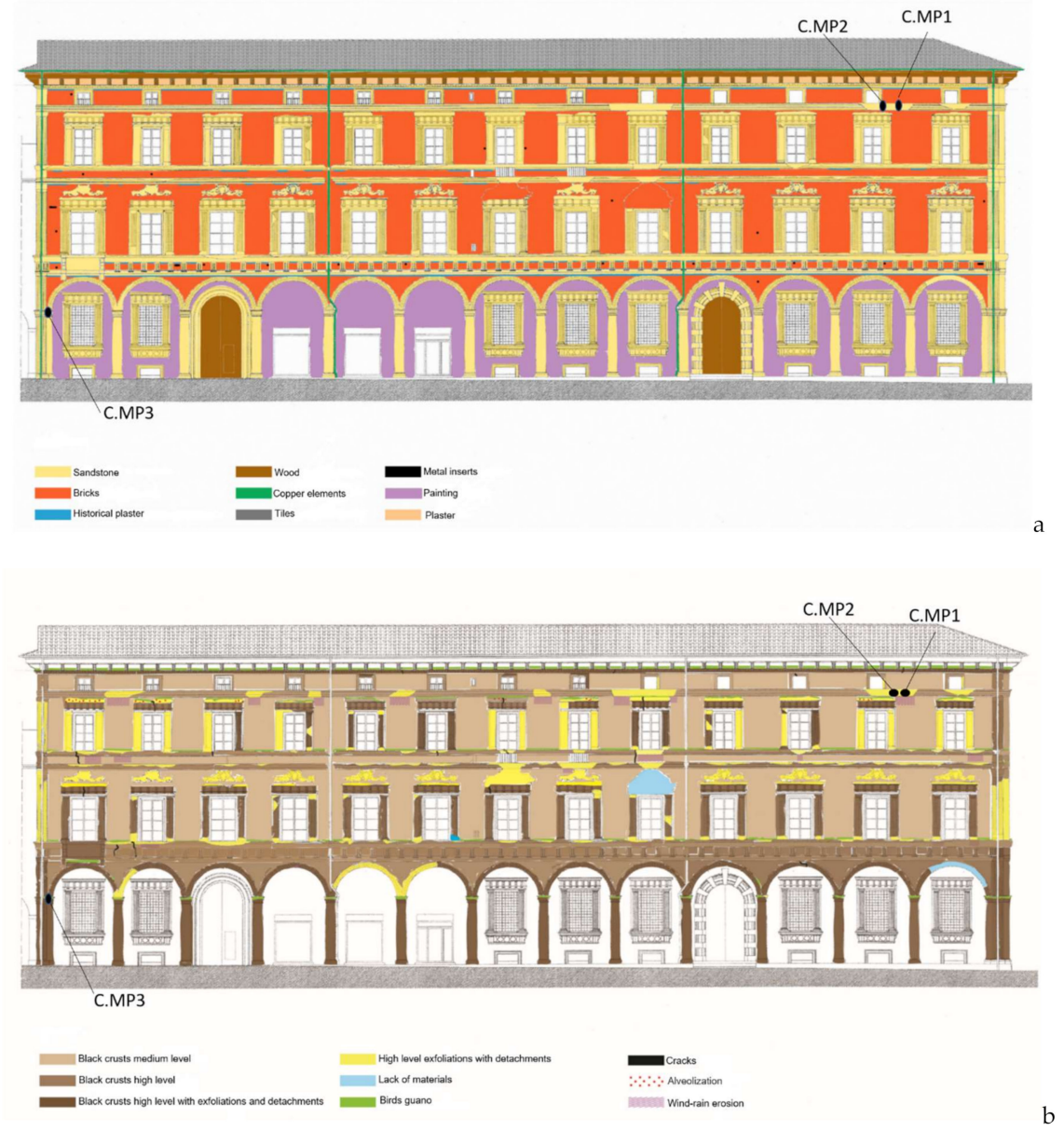

Figure 3. Façade elevation of the Orsi-Marconi Palace with the sampling points called C.MP1, C.MP2, and C.MP3: (a) elevation with in evidence the materials used for the construction of the building; (b) map of the deterioration on the façade of the building.

Thanks to the Superintendence for the Archaeological Heritage of Emilia Romagna, sampling took place in two different stages on time and using a small archaeologist's chisel.

Two samples were collected before the consolidation and cleaning conservative treatments:

- C.MP2: A small sample of yellow sandstone already detached during demolition and belonging to the horizontal sandstone mouldings (Figure 4a);

- C.MP3: A small sample of grey sandstone belonging to the top of a capital on which an arch rests (Figure $4 \mathrm{~b}$ ); a sample of consolidated yellow sandstone was collected following the restoration treatments;

- C.MP1: A sample of consolidated yellow sandstone (Figure 4c) which came off during a grouting operation on a part of the horizontal moulding with an organic consolidating agent (Ethyl Silicate), near the sampling area of the C.MP2 sample. The consolidation treatment was part of previous preservations: the sample was collected after one week from the treatment. The decision to take a consolidated sample with yellow sandstone was due to the fact that this type of material prevailed on the building compared to the grey one. 

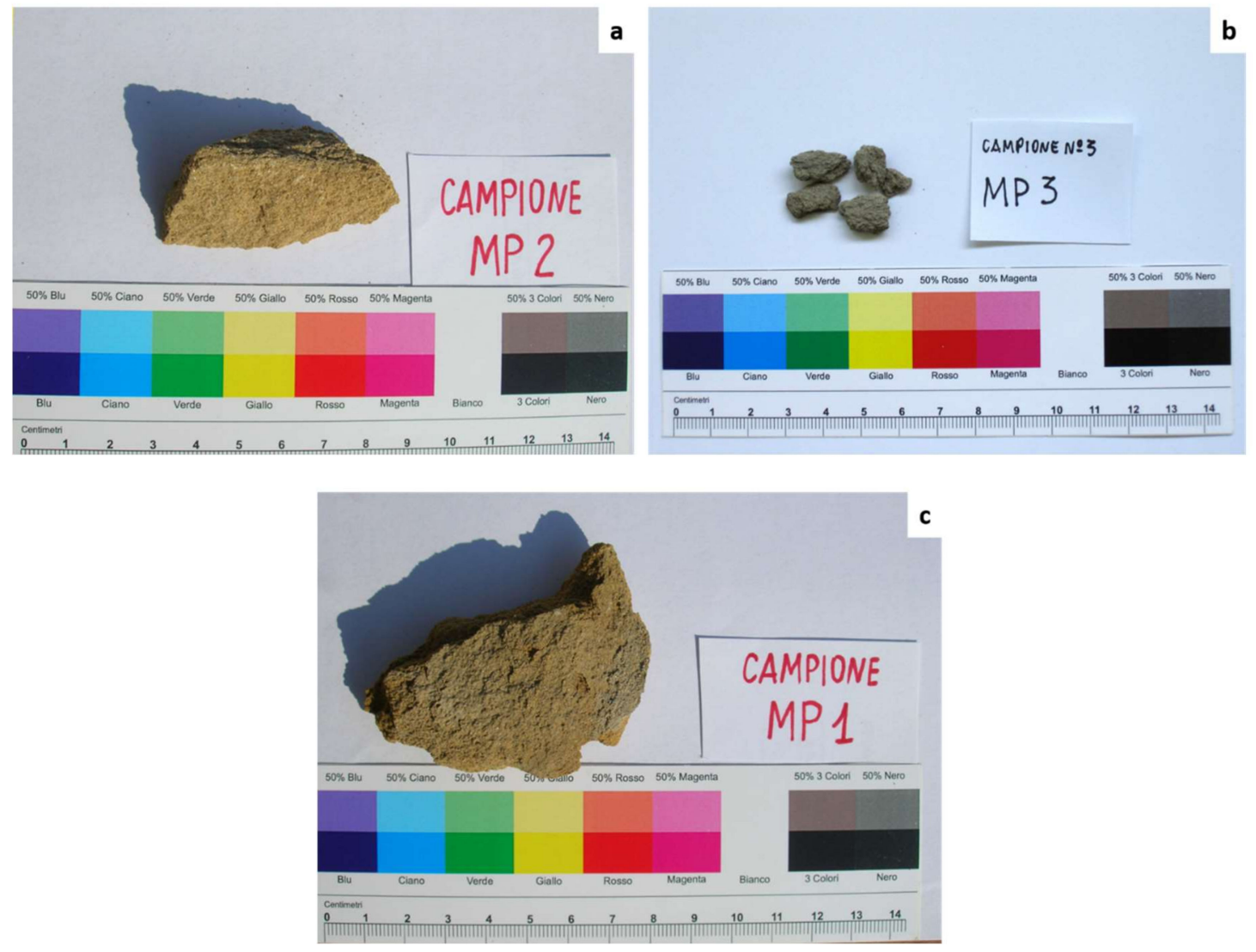

Figure 4. Photo imaging of the samples collected: (a) C.MP2 correspond to unconsolidated yellow sandstone; (b) C.MP3 was sample of unconsolidated grey sandstone; (c) C.MP1 correspond to consolidated yellow sandstone.

\subsection{Chemical and Mineralogical Characterization}

The preparation of the samples and the analyses were carried out in the laboratories of the Department of Physics and Earth Sciences of the University of Ferrara.

Firstly, macroscopic investigations were carried out on all the three samples to define their physical features (grain size, texture, and any treatments), colour, cohesion, and to evaluate the presence of secondary phases (e.g., concretions, incrustations, efflorescence, etc.).

Observation on the surfaces of the samples was carried out using a stereomicroscope (Optika SZ6745TR) on crushed samples and an Optical Transmitted Light Polarized Microscopy (BX51 Olympus) on thin sections. The optical stereomicroscope (90x total magnification) equipped with MOTICAM 2500 5.0M pixel webcam using the Motic Images Plus 2.0 ML software was used for reflected light observation on all the samples to define their structural aspect (grain size and texture), clasts dimensional, and morphological aspect of their state of conservation.

In addition, Optical Transmitted Light Polarized Microscopy (OTLPM) of thin sections is one of the fundamental and widely used techniques for the study of minerals and rocks. In this specific work, OTLPM provided information about the presence of fractures, which is useful data to identify its formation environment and give a name to the studied rock $[33,34]$.

The samples were pulverized using an agate pestle and subsequently incorporated in a tablet prepared with a boric acid support for the chemical characterization by X-ray fluorescence (XRF) analysis using a wavelength-dispersive ARL Advant'XP X-Ray fluorescence spectrometer (Thermo Fisher Scientific) [35,36]. Whole rock major and trace element analyses have been carried out at the Department of Physics and Earth Sciences (University of Ferrara, Italy). This analytical technique allowed the determination of the major elements, expressed as a percentage by oxide weight $\left(\mathrm{SiO}_{2}\right.$, 
$\mathrm{TiO}_{2}, \mathrm{Al}_{2} \mathrm{O}_{3}, \mathrm{Fe}_{2} \mathrm{O}_{3}, \mathrm{MnO}, \mathrm{MgO}, \mathrm{CaO}, \mathrm{Na}_{2} \mathrm{O}, \mathrm{K}_{2} \mathrm{O}, \mathrm{P}_{2} \mathrm{O}_{5}$ ) and of the following trace elements reported in ppm (parts per million): $\mathrm{Ba}, \mathrm{Ce}, \mathrm{Co}, \mathrm{Cr}, \mathrm{La}, \mathrm{Nb}, \mathrm{Ni}, \mathrm{Pb}, \mathrm{Rb}, \mathrm{Sr}, \mathrm{Th}, \mathrm{V}, \mathrm{Y}, \mathrm{Zn}, \mathrm{Zr}, \mathrm{Cu}, \mathrm{Ga}, \mathrm{Nd}, \mathrm{S}$, Sc. The full matrix correction procedure and the intensities were elaborated according to the model proposed by Lachance and Traill [37], Rousseau [38], and Liu [39]. The accuracy of the instrument was estimated on the basis of the results obtained on international standards of geological samples, and the precision was expressed as standard deviation of replicated analyses. The accuracy and precision are better than $2-5 \%$ for major elements and $5-10 \%$ for trace elements. The detection limit is $0.01 \%$ and 1-3 ppm for most of the major and trace element concentrations, respectively.

Moreover, X-ray diffraction allows for the identification of crystalline compounds to trace both the nature of the substance and its crystalline form. Mineralogical characterization of the samples, previously grinded, using water, then dried and powdered within an agate mill was carried out by X-ray diffraction (XRD) by means of a PW1860/00 diffractometer (Philips), with a graphite filtered and a $\mathrm{Cu} \mathrm{K} \alpha$ radiation $(1.54 \AA)$ in a $2 \theta$ angular range $5-75^{\circ}$, with a $5 \mathrm{~s} / \mathrm{step}\left(0.02^{\circ} 2 \theta\right)$. Diffraction patterns were collected in the $2 \theta$ angular range $3-50^{\circ}$, with a $5 \mathrm{~s} /$ step $(0.022 \theta)[34,40]$.

\section{Results}

\subsection{Macroscopic Characterization: Colors and Shape}

Macroscopic investigations were carried out on all the samples collected.

The observation of the C.MP2 sample showed an unconsolidated yellow sandstone with a medium-fine grain size with clastic laminar texture on the parallel plane and cross-lamination at a low angle and concave cross (Figure 5a). There were also thin conglomeratic alignments and occasionally rounded gravels. The light yellow and ochre colour could correspond to levels with higher concentration of iron oxides oriented along the lamination. The sample appeared de-cohesive due to the small compactness of the single sand grains; all this was probably caused by a high state of degradation.
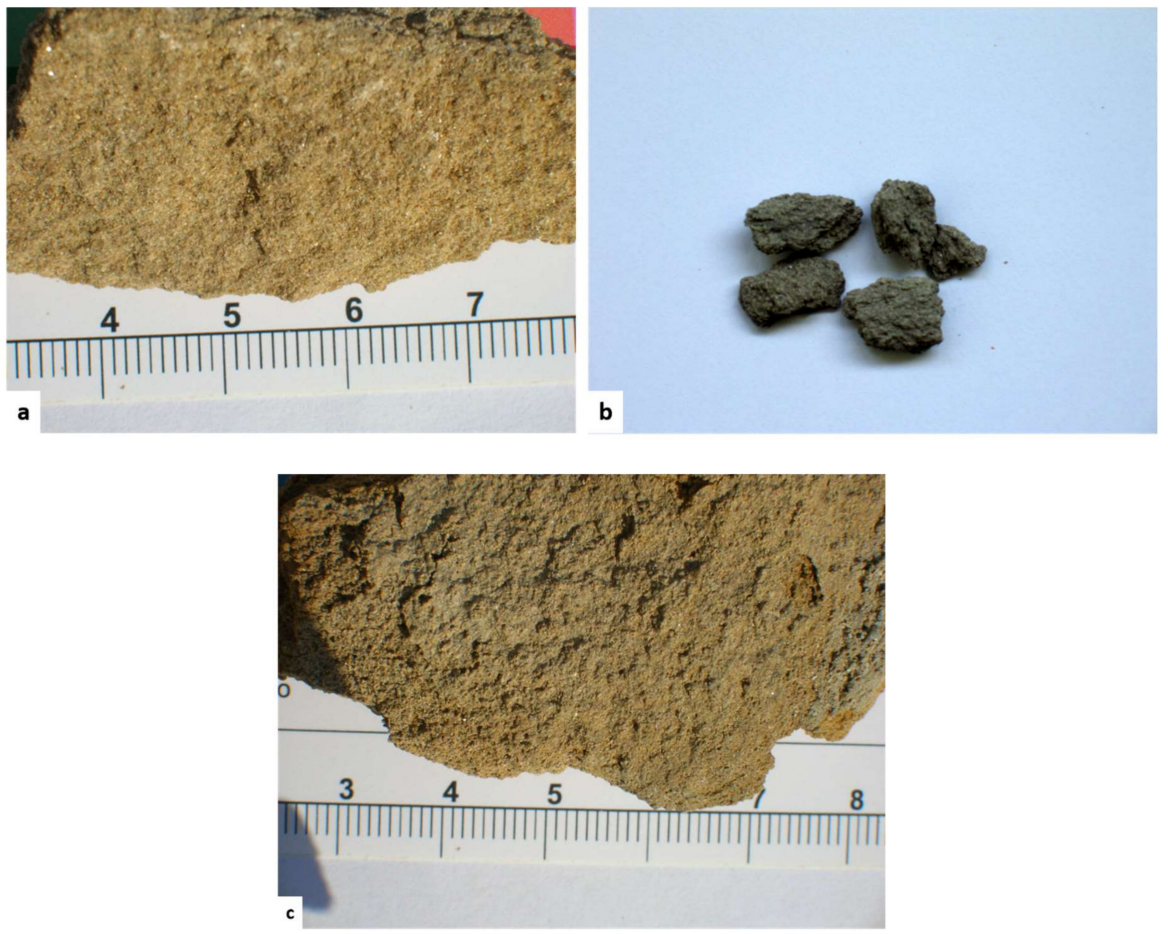

Figure 5. Detail photo of the three samples observed through macroscopic observations: (a) C.MP2 sample of unconsolidated yellow sandstone; (b) C.MP3 sample of unconsolidated grey sandstone; (c) C.MP1 sample of consolidated yellow sandstone. 
The observation of the C.MP3 sample showed an unconsolidated grey sandstone with a very fine grain size, also with clastic laminar texture on the parallel plane; overall, it appeared coherent (Figure $5 b$ ). It generally had a light grey colour. The sample also appeared de-cohesive, in this case probably due to a high state of degradation as for sample C.MP2.

Finally, C.MP1 sample showed a consolidated sandstone with greater cohesion and compactness of the stone, with grains strongly aggregated by the consolidating agent (Figure 5c). The colour of the sample was yellow and it appeared slightly lightened by the consolidating agent, but the variation could depend on the fact that the sample was collected after only one week from the treatment; in fact, under optimal atmospheric conditions, the consolidating agent was absorbed on average three weeks after the treatment.

\subsection{Optical Microscopic Characterization}

The optical stereomicroscope on the samples made it possible to recognize the characteristics of the morphological and structural aspect of the different samples.

Figure 6a shows the $35 \mathrm{x}$ magnification microscopic analysis of the C.MP2 sample. It was possible to observe the individual granules of the unconsolidated yellow sandstone: their size was homogeneous and the clasts were rounded. Quartz and mica (muscovite and biotite) were well observed.
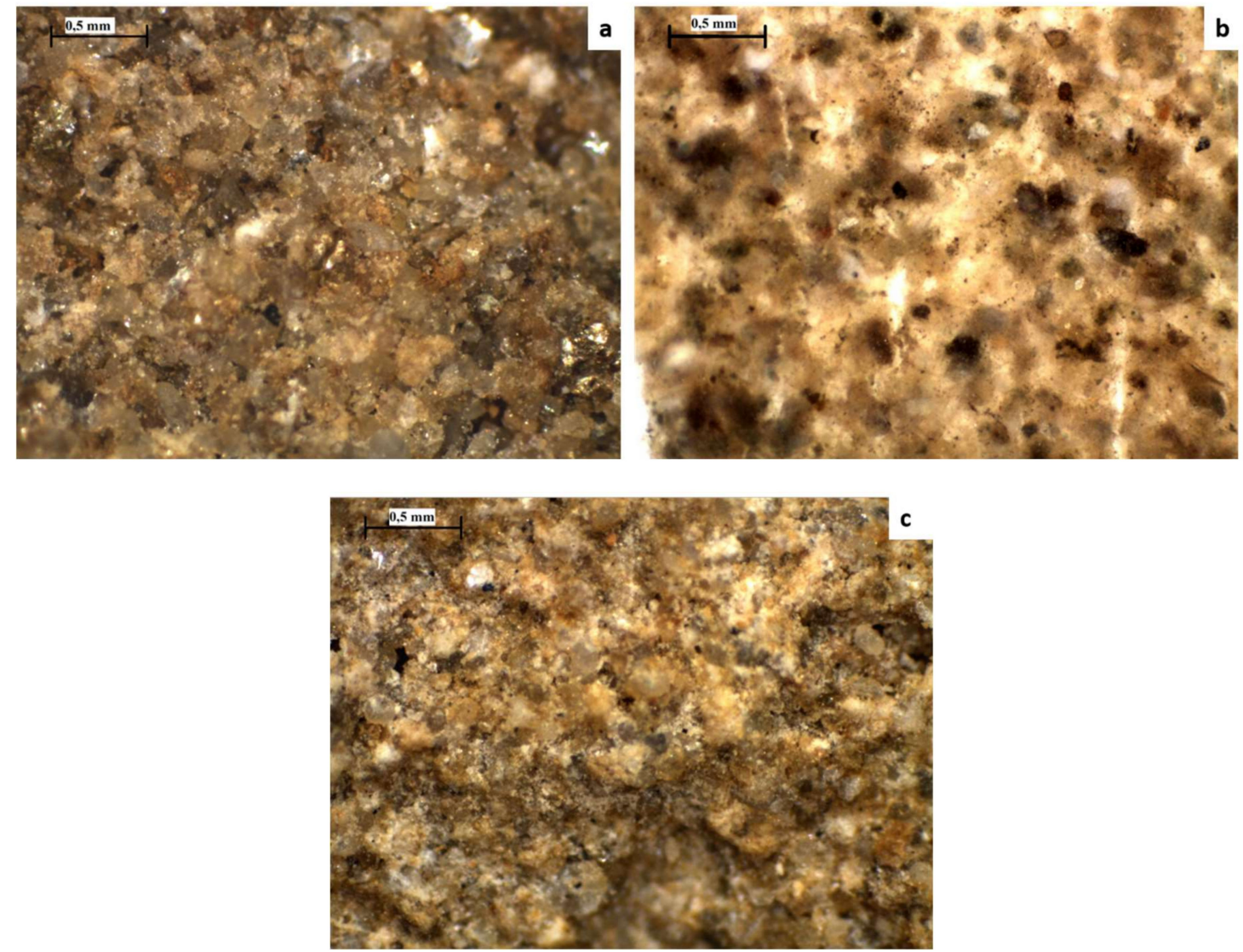

Figure 6. Photo images of the samples analysed by reflected light optical microscope at $35 \mathrm{x}$ magnification: (a) C.MP2 sample; (b) C.MP3 sample; (c) C.MP1 sample.

Figure $6 \mathrm{~b}$, on the other hand, shows the $35 \mathrm{x}$ magnification analysis of the C.MP3 sample. The grains of unconsolidated grey sandstone were smaller than those of the yellow sandstone (C.MP2).

Figure $6 \mathrm{c}$ shows the microscopic observation of the C.MP1 sample at $35 \mathrm{x}$ magnification. The grains of the consolidated yellow sandstone were less noticeable due to the evident presence of consolidate 
material which appears whitish in colour. The overall appearance of the grain size was more compact than the previous samples.

The analysis of the thin sections through optical transmitted light microscopy highlighted the main characteristics of the sandstone, allowing for a comparison between the yellow and grey type and between the one treated with consolidating agent and the untreated one.

Figure 7a shows the photo imaging of the sample C.MP2 at $25 \times$ magnification and crossed nicols. The yellow sandstone showed strong de-cohesion between the individual granules which were characterized by rounded but isolated edges; cement was characterized by carbonate and locally silicate. The grains were moderately fine.
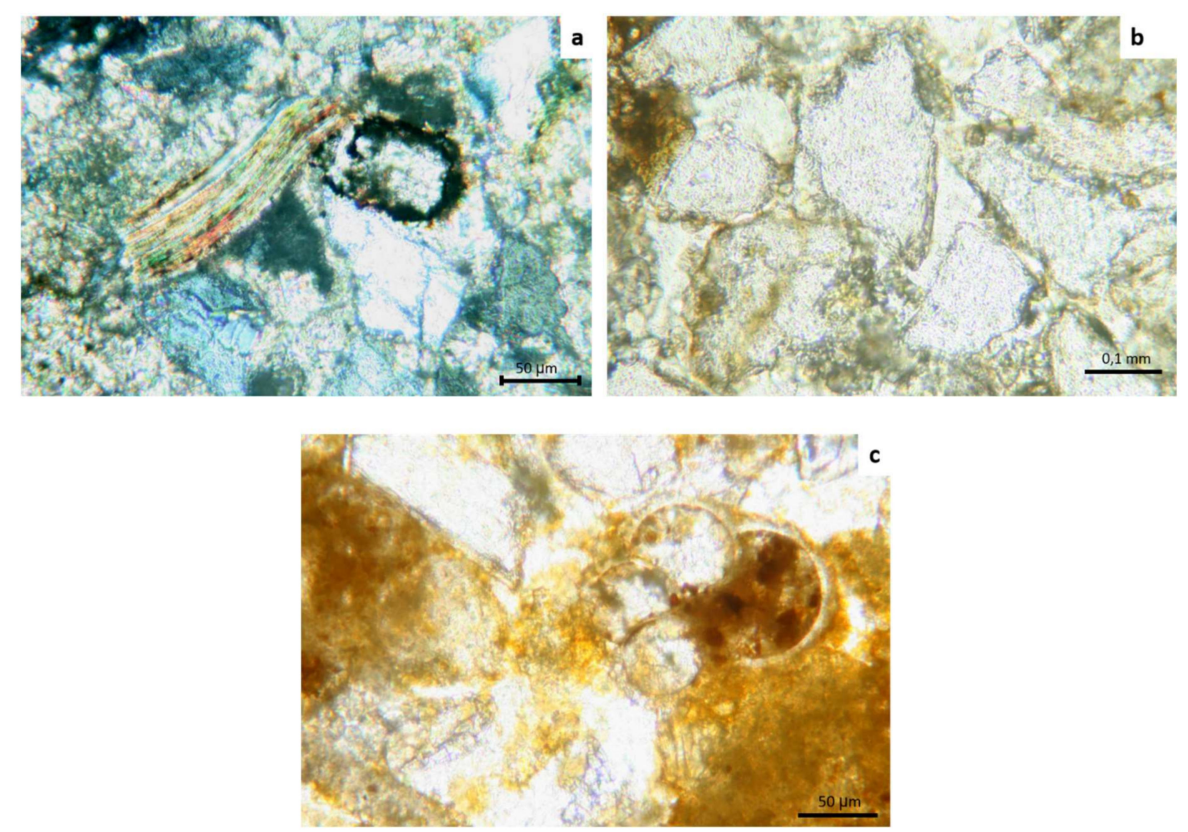

Figure 7. Photo images obtained by the optical transmitted light microscopy of the thin sections of the samples at 25x magnification: (a) C.MP2 (crossed nicols); (b) C.MP3 (parallel nicols); (c) C.MP1 (parallel nicols).

The grey sandstone of the C.MP3 sample (Figure 7b) -magnification $25 \mathrm{x}$ at crossed nicols) had a greater number of fractures than the yellow one which increased its porosity (secondary); moreover, it was possible to notice that they were all oriented. A finer grain than the yellow one was observed. Mineral characteristics of these sandstones were visible: Alkaline feldspar (probably orthoclase due to the clearly visible cleavage traces), phyllosilicates of the chlorite group (green-yellowish in colour), and quartz. In the foreground, an altered biotite with overlapping sheets (usually hexagonal) was clearly visible. Green glauconite was clearly visible, an accessory mineral typical of these types of sandstone.

The observations of the sample C.MP1 at $25 \mathrm{x}$ magnification and parallel nicols showed spheres of foraminiferal shells, in which the darker coloured organic component was clearly distinguished inside. These were probably globigerine, benthic foraminifera typical of a marine Quaternary sedimentation environment (Figure 7c) [41,42]. Inside the clasts and fractures of the consolidated yellow sandstone, it was possible to observe the consolidating agent (greyish). Overall, the clasts appeared more cohesive.

\subsection{XRPD Data Analysis}

Figure 8 shows the spectra of the three analysed samples, which allowed to compare the characteristics of the samples analysed with other techniques. The main minerals analysed were calcite 
(Cal), quartz $(\mathrm{Qz})$, albite $(\mathrm{Ab})$, dolomite (Dol), muscovite $(\mathrm{Ms})$, biotite $(\mathrm{Bt})$, microciline $(\mathrm{Mc})$, sodalite (Sdl), and augite (Aug), as shown in Figure 8.
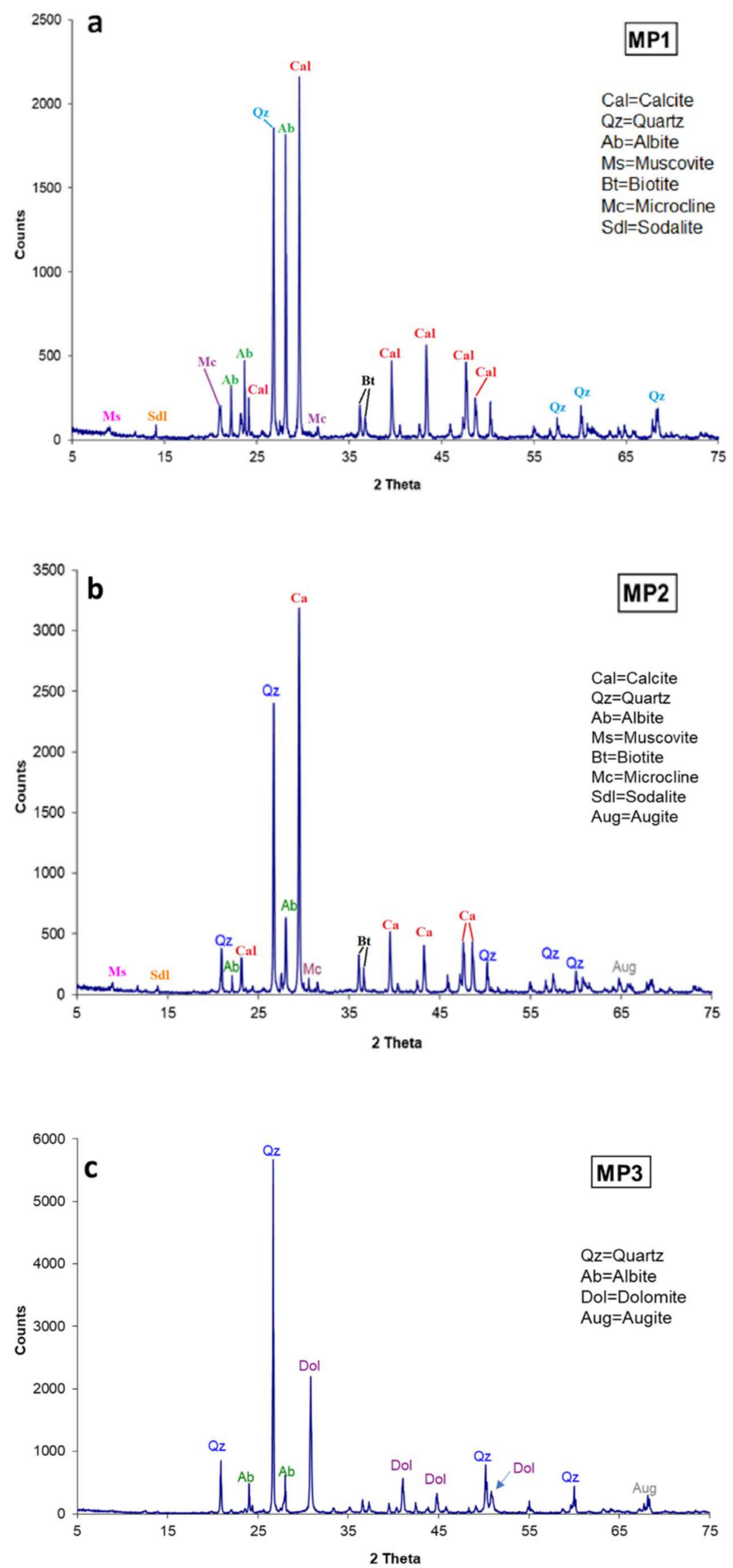

Figure 8. X-Ray Powder Diffractometric (XRPD) spectrum of the three samples analysed: (a) C.MP1 sample; (b) C.MP2 sample; (c) C.MP3 sample.

The C.MP1 sample (Figure 8a) showed a strong presence of calcite (peak of Cal) in addition to that of quartz, feldspars, such as albite and microcline, and micas, muscovite, and biotite. From diffractometric 
analyses, however, no changes in mineralogical levels emerged due to the presence of the consolidating agent (Ethyl Silicate); this was probably due to the fact that this analytical typology did not detect organic substances, which was the nature of the consolidating agent used; therefore, the silicate could only be identified through chemical analysis.

The diffractometric analysis of the C.MP2 sample (Figure 8b) showed as main mineralogical phases quartz, plagioclase, K-feldspar, phyllosilicates, and calcite; this latter phase is present in large quantities. The yellow sandstone belonged to the late Pliocene-lower Pleistocene period that was characterized by a strong presence of Foraminifera (as also observed in the optical transmitted light microscopy observations); these shells cemented the sediment of loose sand. The presence of quartz was significant and also other sialic minerals such as albite and microcline, but there were also femic minerals, such as muscovite, biotite, and augite (calcium clinopyroxene).

Figure $8 \mathrm{c}$ showed the absence of calcite in the C.MP3 grey sandstone sample, presumably caused by the low presence of Foraminifera in the Miocene (period of formation of this rock) compared to the period of formation of the yellow sandstone. In this sample, there was a large quantity of quartz (high peak) and some peaks of albite and augite (calcium clinopyroxene). In addition, dolomite, a mineral enriched in $\mathrm{Mg}$, was very abundant. Glauconite, observed through petrographic microscope, was not visible in the diffractometric analysis presumably due to its low percentage that was not detected.

\subsection{XRF Data Analysis}

Table 1 shows the data relating to the chemical elements analysed in the different sandstone samples. All the samples were characterized by a high value of silica and calcium. In particular, the samples C.MP1 and C.MP2 showed a similar composition, respective to sample C.MP3 both in the major oxides (Table 1) of that in the trace elements (Table 2).

Table 1. X-ray fluorescence (XRF) data of major oxides expressed in weight oxide (\%) in the analysed samples.

\begin{tabular}{lccc}
\hline \multicolumn{1}{c}{ Oxides } & C.MP2 & C.MP3 & C.MP1 \\
\hline $\mathrm{SiO}_{2}$ & 38.06 & 41.53 & 42.06 \\
$\mathrm{TiO}_{2}$ & 0.17 & 0.15 & 0.22 \\
$\mathrm{Al}_{2} \mathrm{O}_{3}$ & 4.53 & 4.71 & 5.53 \\
$\mathrm{Fe}_{2} \mathrm{O}_{3}$ & 1.64 & 2.71 & 2.96 \\
$\mathrm{MnO}$ & 0.08 & 0.13 & 0.13 \\
$\mathrm{MgO}$ & 1.10 & 10.41 & 1.07 \\
$\mathrm{CaO}$ & 31.10 & 16.97 & 26.74 \\
$\mathrm{Na} 2 \mathrm{O}$ & 0.70 & 0.62 & 0.70 \\
$\mathrm{~K}_{2} \mathrm{O}$ & 0.73 & 0.85 & 0.93 \\
$\mathrm{P}_{2} \mathrm{O}_{5}$ & 0.07 & 0.10 & 0.07 \\
$\mathrm{LOI}$ & 21.81 & 21.82 & 19.58 \\
$\mathrm{TOT}$ & 100 & 100 & 100 \\
\hline
\end{tabular}

First of all, there was an increase in the oxide weight percentage of $\mathrm{SiO}_{2}$ in the C.MP1 sample compared to that of the C.MP2 sample; this probably comes from the presence of the consolidating agent (Ethyl Silicate), which increased the quantity of silica inside the stone.

The C.MP3 sample shows less value of calcium and a high value of $\mathrm{MgO}$ respective to the other two samples (Table 1), probably due to the significant presence of dolomite $\left(\mathrm{Ca}, \mathrm{Mg}\left(\mathrm{CO}_{3}\right)_{2}\right)$. The same sample also showed an extremely high quantity of zinc (Table 2), probably caused by pollutants deposited in large quantities in the sample collection area [43].

In all the samples, a high concentration of sulphur was founded, as shown in Table 2, which is one of the main decay factors of carbonate-based stones in polluted environments [44,45]. A high concentration of barium related to a high concentration of calcium ions could be originated from the decomposition of primary aluminosilicates (calcium also from dissolution of carbonates) of the 
sandstones. Nevertheless, significant amounts of these elements may also be linked with particulate air pollutants [46-48] and capillary transport from the ground. In particular, the evaluation of the geochemical composition, in terms of trace elements, can contribute to the understanding of the influence of pollution sources in the formation processes of this degradation product. However, some aspects of the distribution of metals within the crust and the substrate are still unclear.

As indicated by McAlister et al. [49,50], Zn concentrations could be related to atmospheric pollution.

Table 2. XRF data of trace elements expressed in ppm (n.d. = not detected) in the analysed samples.

\begin{tabular}{lccc}
\hline Trace Elements & C.MP2 & C.MP3 & C.MP1 \\
\hline $\mathrm{Ba}$ & 119.5 & 172.6 & 156.3 \\
$\mathrm{Ce}$ & n.d. & n.d. & 0.5 \\
$\mathrm{Co}$ & 0.5 & 3.4 & 3.0 \\
$\mathrm{Cr}$ & 16.8 & 29.4 & 27.3 \\
$\mathrm{La}$ & 2.6 & 3.7 & 5.7 \\
$\mathrm{Nb}$ & n.d. & n.d. & 0.3 \\
$\mathrm{Ni}$ & 10.8 & 12.7 & 31.7 \\
$\mathrm{~Pb}$ & 10.9 & 9.1 & 13.8 \\
$\mathrm{Rb}$ & 22.0 & 30.6 & 27.9 \\
$\mathrm{Sr}$ & 248.0 & 225.4 & 258.8 \\
$\mathrm{Th}$ & 0.8 & 2.2 & 1.2 \\
$\mathrm{~V}$ & 18.5 & 18.8 & 26.6 \\
$\mathrm{Y}$ & 9.6 & 7.7 & 10.8 \\
$\mathrm{Zn}$ & 13.3 & 1096.0 & 21.7 \\
$\mathrm{Zr}$ & 140.9 & 224.2 & 145.4 \\
$\mathrm{Cu}$ & 14.8 & 28.2 & 12.5 \\
$\mathrm{Ga}$ & 6.4 & 5.6 & 6.9 \\
$\mathrm{Nd}$ & 6.5 & 4.2 & 5.2 \\
$\mathrm{~S}$ & 3796.1 & 448.9 & 5544.4 \\
\hline
\end{tabular}

\section{Discussion}

The use of yellowish sandstones in the Bologna surrounding has been documented since the 8 th and 6th centuries BC. From the 13th to the 16th century, the Varignana Sandstone, belonging to the Umbro-Romagnolo Domain ("Sabbie Gialle" Formation of Pleistocene age), has been commonly employed in Bologna buildings (e.g., Palazzo del Podestà, Palazzo Malvezzi and many others) [51]. The first quarries of these yellowish sandstones were opened in the Southern part of the medieval city of Bologna. Later, new quarries were opened in the Varignana area, a place belonging to the municipality of Castel San Pietro Terme (very close to Bologna city), where two opened quarries remained active since Roman times, until the Second World War, and still exists [51]. The Varignana Sandstones are classified as hybrid arenites passing into calclithytes with grainsize ranges from fine to very fine. The sandstones from the quarries show a typical yellowish colour and cross lamination. Bioclasts are represented by relicts of foraminifer shells, mainly Globigerinae. Quartz, feldspars, and micas (biotite, chlorite, muscovite) are the main siliclastic components, while calciclastic components are made of micritic grains and sparitic calcite crystals. Rock fragments probably come from the Apennine and include fragments of metamorphic rocks, siltite, argillite, and basic vulcanite. Garnet, epidote, spinel, pyrite, glauconite, zircon, and apatite can appear as accessory minerals. The matrix and cementation are mainly carbonates.

The yellow sandstones analysed in this work and represented by the samples C.MP1 and C.MP2 were characterised by silica, mica, and calcium carbonate. These data were also confirmed by the XRD analyses. Magnesium carbonate was sometimes present but around $1 \%$ and probably related to the cementer of sand grains. On the other hand, grey sandstone (in this work sample C.MP3) presented less value of calcium concentration because C.MP3 sample was mainly due from dolomite (less value of calcium and a high value of $\mathrm{MgO}$ ). As for the main parts of the Bologna historical buildings, it could 
hypothesize that Varignana sandstone has been used also for the decorations of the Orsi-Marconi Palace façade. The presence of glauconite in the sample C.MP3 is in accordance with the data obtained by Marszałek et al. [52]. The presence of glauconite could be related to other aluminosilicate, such as micas and feldspars. Air pollution and climate strongly affects the integrity of buildings (and consequently building materials promoting their degradation over time, especially in an urban context). The impact of atmospheric pollution on building materials differs widely with the material; in fact, lithology is an important control on alteration and decay effects. Some stones, such as granite, are very resistant to weathering; on the contrary, porous limestone and sandstones degrade more rapidly under the action of the weather and other environmental attacks. Sandstone decay in a polluted urban atmosphere may be rapid and cause marked surface change within a short period relative to the life expectancy of stone buildings and monuments [53].

As in Martinez-Arkarazo et al. [54] and Marszałek et al. [52], in all the samples, the presence of elements related to pollutant impact were identified. Lead was an original component of the stones; in fact, according to the results summarised in Table 2, it appeared at similar concentration levels in all the samples: higher in the grey sandstone (C.MP3 sample) compared to yellow sandstones (C.MP1 and C.MP2 samples). Sulphur concentration in the yellow sandstones (C.MP1 and C.MP2 samples) was at least 10 times higher than in the grey sandstone (C.MP3 sample). The main source of sulphur was probably calcium sulphate, and it was indicative of the higher deterioration of this stone type [52]. In addition, this contaminant must be the reason of the presence of gypsum [55] as degradation products, especially in the yellow sandstones, as described in the other two works compared. Finally, the high concentration of copper was probably related to particulate matter in the urban atmospheres [50,52]. Lead and sulphur were supposed to come from fuel's combustion since the Orsi-Marconi Palace is located in an area affected by road traffic, as the palace house is in the metropolitan Bilbao [54].

Taking into consideration these scientific papers confirmed that the chemical composition of the black crusts indicates that their development is controlled by the environmental conditions combined, in particular, with climate and pollution.

\section{Conclusions}

The mineralogical and chemical characterization of the natural stone materials used to decorate the façade of Palazzo Orsi-Marconi in Bologna made it possible to identify the type of the natural material used and the quarry of origin, comparing the results obtained from the analyses with bibliography works. The data obtained revealed that this building was adorned with sandstone architectural elements. The stone material used was predominantly the yellow sandstone from the Varignana quarries, a restricted area in the Apennine, in the municipality of Castel San Pietro Terme (BO). This stone material has been frequently used in several historical buildings in Bologna in the past and a petro-mineralogical study approach could be extended to other Bologna buildings, in order to compare the different stone materials, the related quarries of extraction, and the different responses to degradation to improve their state of conservation evaluation.

The mineralogical and chemical characterization of the materials used to build the façade of the Orsi-Marconi Palace in Bologna also made it possible to:

- evaluate the impact on the stone conservation of air pollution and meteoric water;

- determine that the concentration of specific elements (such as $\mathrm{Ba}, \mathrm{Zn}, \mathrm{Zr}$, etc.) was higher in the yellow sandstone samples, evidencing the fingerprint of air pollution due to vehicular emissions; consider the evolution of the conservation state of the rock substrate. The abundance of some elements, such as $\mathrm{Zn}, \mathrm{Cu}, \mathrm{Ni}$, etc., were usually higher in the substrate, coupled with the presence of a network of microcracks, that could also lead to the formation of new crusts contributing to the acceleration of weathering damage. 
The results obtained represent a further milestone for better managing future restoration interventions, especially in terms of choice of the best cleaning procedures for historical and monumental complexes. Additionally, suitable consolidation procedures will make it possible to increase the resistance of stone materials against the degradation phenomena mainly related to the geochemical mobility from the black crusts to the substrate.

Author Contributions: Conceptualization: E.M., C.T., and C.V.; data curation: E.M., M.P., C.T., and C.V.; formal analysis: E.M., M.P., and C.V.; funding acquisition: C.V.; investigation: E.M., C.T., M.P., and C.V.; methodology: E.M., C.T., and C.V.; resources: C.V.; supervision: E.M. and C.V.; writing-original draft: E.M., C.T., M.P., and C.V.; writing - review and editing: E.M., C.T., and C.V. All authors have read and agreed to the published version of the manuscript.

Funding: This research received no external funding.

Acknowledgments: We want to thank the direction of the Superintendence for the Archaeological Heritage of Emilia Romagna for making the samples available. This research was supported through a fellowship of the University of Ferrara. We would like to thank Tassinari Renzo of the Department of Physics and Earth Sciences, University of Ferrara, for chemical analyses.

Conflicts of Interest: The authors declare no conflict of interest.

\section{References}

1. Guidicini, G. Cose Notabili Della Città di Bologna: Ossia Storia Cronologica de' Suoi Stabili Sacri, Pubblici e Private; Forni, A., Ed.; Arnaldo Forni: Bologna, Italy, 1972.

2. Manzini, G. Antonio Morandi, “il Terribilia”, nell'architettura bolognese del '500. Il Carrobbio. Rivista di Studi Bolognesi 1983, 9, 243-255.

3. Bacci, P.; Del Monte, M.; Sabbioni, C.; Zappia, G. Black Crusts as Air Pollution Indicators. In Proceedings of the European Symposium, Bologna, Italy, 13-16 June 1991; pp. 462-464.

4. Violante, F.S.; Barbieri, A.; Curti, S.; Sanguinetti, G.; Graziosi, F.; Mattioli, S. Urban atmospheric pollution: Personal exposure versus fixed monitoring station measurements. Chemosphere 2006, 64, 1722-1729. [CrossRef] [PubMed]

5. Sarti, E.; Pasti, L.; Rossi, M.; Ascanelli, M.; Pagnoni, A.; Trombini, M.; Remelli, M. The composition of PM 1 and PM 2.5 samples, metals and their water soluble fractions in the Bologna area (Italy). Atmospheric Pollut. Res. 2015, 6, 708-718. [CrossRef]

6. Comite, V.; De Buergo, M.A.; Barca, D.; Belfiore, C.; Bonazza, A.; La Russa, M.; Pezzino, A.; Randazzo, L.; Ruffolo, S. Damage monitoring on carbonate stones: Field exposure tests contributing to pollution impact evaluation in two Italian sites. Constr. Build. Mater. 2017, 152, 907-922. [CrossRef]

7. Ortíz, R.; Ortiz, P.; Vázquez, M.; Martín, J. Integration of georeferenced informed system and digital image analysis to asses the effect of cars pollution on historical buildings. Constr. Build. Mater. 2017, 139, 320-333. [CrossRef]

8. Graue, B. Environmental Impact on Stone Decay: Crust Formation at the Cologne Cathedral. In Proceedings of the International Congress on Deterioration and Conservation of Stone, New York, NY, USA, 21-25 October 2012; p. 13.

9. Balog, A.A.; Corbizan, N.; Mosonyi, E. Analysis of Limestones from Heritage Buildings as Damage Diagnostics. Rom. Rep. Phys. 2016, 68, 353-361.

10. Farkas, O.; Siegesmund, S.; Licha, T.; Török, Á. Geochemical and mineralogical composition of black weathering crusts on limestones from seven different European countries. Environ. Earth Sci. 2018, 77. [CrossRef]

11. Çelik, M.Y.; Kaçmaz, A.U. The investigation of static and dynamic capillary by water absorption in porous building stones under normal and salty water conditions. Environ. Earth Sci. 2016, 75. [CrossRef]

12. Sun, Q.; Dong, Z.; Jia, H. Decay of sandstone subjected to a combined action of repeated freezing-thawing and salt crystallization. Bull. Int. Assoc. Eng. Geol. 2019, 78, 5951-5964. [CrossRef]

13. Benavente, D.; Martínez-Martínez, J.; Cueto, N.; Ordóñez, S.; Garcia-Del-Cura, M.A. Impact of salt and frost weathering on the physical and durability properties of travertines and carbonate tufas used as building material. Environ. Earth Sci. 2018, 77. [CrossRef]

14. Lubelli, B.; Cnudde, V.; Diaz-Goncalves, T.; Franzoni, E.; Van Hees, R.P.J.; Ioannou, I.; Menéndez, B.; Nunes, C.; Siedel, H.; Stefanidou, M.; et al. Towards a more effective and reliable salt crystallization test for porous building materials: State of the art. Mater. Struct. 2018, 51. [CrossRef] 
15. Mosoarca, M.; Keller, A.I.; Petrus, C.; Racolta, A. Failure analysis of historical buildings due to climate change. Eng. Fail. Anal. 2017, 82, 666-680. [CrossRef]

16. Cavalagli, N.; Kita, A.; Castaldo, V.; Pisello, A.L.; Ubertini, F. Hierarchical environmental risk mapping of material degradation in historic masonry buildings: An integrated approach considering climate change and structural damage. Constr. Build. Mater. 2019, 215, 998-1014. [CrossRef]

17. El-Gohary, M.A. Environmental impacts: Weathering factors, mechanism and forms affected the stone decaying in Petra. J. Afr. Earth Sci. 2017, 135, 204-212. [CrossRef]

18. Di Turo, F.; Proietti, C.; Screpanti, A.; Fornasier, M.F.; Cionni, I.; Favero, G.; De Marco, A. Impacts of air pollution on cultural heritage corrosion at European level: What has been achieved and what are the future scenarios. Environ. Pollut. 2016, 218, 586-594. [CrossRef]

19. Mooers, H.; Carlson, M.; Harrison, R.M.; Inkpen, R.; Loeffler, S. Correlation of gravestone decay and air quality 1960-2010. Atmospheric Environ. 2017, 152, 156-171. [CrossRef]

20. Janvier-Badosa, S.; Beck, K.; Brunetaud, X.; Al-Mukhtar, M. The SACRE Project: A Diagnosis Tool of Built Heritage. Computer Vision 2016, 10058, 681-690. [CrossRef]

21. Gonçalves, J.; Mateus, R.; Silvestre, J.D. Comparative Analysis of Inspection and Diagnosis Tools for Ancient Buildings; Springer: Berlin, Germany, 2018; pp. 289-298.

22. Cantisani, E.; De Luca, D.; Frediani, P.; Garzonio, C.A.; Ricci, M.; Stori, F. Restoration of a Sandstone Facade: From the Project to the Monitoring. Int. J. Arch. Heritage 2012, 6, 290-301. [CrossRef]

23. Briceño, C.; Gonzales, M.; Yaya, C.; Moreira, S.; Aguilar, R. Preliminary Structural Diagnosis of the Sacsamarca Church in Peru Using Photogrammetry and IR Thermography; Springer: Berlin, Germany, 2019; Volume 18, pp. 2431-2438.

24. Sabbioni, C. Characterization of Atmospheric Particles on Monuments by Scanning Electron Microscopy/Energy Dispersive X-ray Analyses. Electron Microsc. 1992, 2, 773-777.

25. Sabbioni, C. Contribution of atmospheric deposition to the formation of damage layers. Sci. Total. Environ. 1995, 167, 49-55. [CrossRef]

26. Turkington, A.; Martin, E.; Viles, H.; Smith, B. Surface change and decay of sandstone samples exposed to a polluted urban atmosphere over a six-year period: Belfast, Northern Ireland. Build. Environ. 2003, 38, 1205-1216. [CrossRef]

27. Korkanç, M. Deterioration of different stones used in historical buildings within Nigde province, Cappadocia. Constr. Build. Mater. 2013, 48, 789-803. [CrossRef]

28. Bonazza, A.; Sabbioni, C.; Ghedini, N. Quantitative data on carbon fractions in interpretation of black crusts and soiling on European built heritage. Atmospheric Environ. 2005, 39, 2607-2618. [CrossRef]

29. La Russa, M.F.; Belfiore, C.M.; Comite, V.; Barca, D.; Bonazza, A.; Ruffolo, S.A.; Crisci, G.M.; Pezzino, A. Geochemical study of black crusts as a diagnostic tool in cultural heritage. Appl. Phys. A 2013, 113, 1151-1162. [CrossRef]

30. Barca, D.; Comite, V.; Belfiore, C.M.; Bonazza, A.; La Russa, M.F.; Ruffolo, S.A.; Crisci, G.M.; Pezzino, A.; Sabbioni, C. Impact of air pollution in deterioration of carbonate building materials in Italian urban environments. Appl. Geochem. 2014, 48, 122-131. [CrossRef]

31. La Russa, M.F.; Fermo, P.; Comite, V.; Belfiore, C.M.; Barca, D.; Cerioni, A.; De Santis, M.; Barbagallo, L.F.; Ricca, M.; Ruffolo, S.A. The Oceanus statue of the Fontana di Trevi (Rome): The analysis of black crust as a tool to investigate the urban air pollution and its impact on the stone degradation. Sci. Total. Environ. 2017, 593-594, 297-309. [CrossRef]

32. Barca, D.; Belfiore, C.M.; Crisci, G.M.; La Russa, M.F.; Pezzino, A.; Ruffolo, S.A. A new methodological approach for the chemical characterization of black crusts on building stones: A case study from the Catania city centre (Sicily, Italy). J. Anal. At. Spectrom. 2011, 26, 1000-1011. [CrossRef]

33. Marrocchino, E.; Fried, A.; Koulouris, A.; Vaccaro, C. Micro-chemical/structural characterisation of thin layer masonry: A correlation with engineering performance. Constr. Build. Mater. 2009, 23, 582-594. [CrossRef]

34. Marrocchino, E.; Telloli, C.; Caraccio, S.; Guarnieri, C.; Vaccaro, C. Medieval Glassworks in the City of Ferrara (North Eastern Italy): The Case Study of Piazza Municipale. Heritage 2020, 3, 819-837. [CrossRef]

35. Marrocchino, E.; Rapti-Caputo, D.; Vaccaro, C. Chemical-mineralogical characterisation as useful tool in the assessment of the decay of the Mesola Castle (Ferrara, Italy). Constr. Build. Mater. 2010, 24, 2672-2683. [CrossRef]

36. Franzini, M.; Randazzo, L.; Saitta, M. Revisione di una Metodologia Analitica per Fluorescenza-x, Basata sulla Correzione Completa degli Effetti di Matrice. Soc. It. Mineral. E Petrol. Rendiconti 1975, 31, 365-378.

37. Lachance, G.R.; Traill, R.J. Practical Solution to the Matrix Problem in X-ray Analysis. Can. Spetrosc. 1966, 11, 43-48. 
38. Rousseau, R.M. Corrections for matrix effects in X-ray fluorescence analysis-A tutorial. Spectrochim. Acta Part B At. Spectrosc. 2006, 61, 759-777. [CrossRef]

39. Liu, H.; Zhou, X.; Zhang, X.; Wu, K.; Lu, C. Experimental Study and Matrix Effect Correction of Pseudobinary Samples in XRF Analysis. IOP Conf. Series: Mater. Sci. Eng. 2018, 389. [CrossRef]

40. Bergamaschi, B.; Marzola, L.; Radice, M.; Manfredini, S.; Baldini, E.; Vicentini, C.B.; Marrocchino, E.; Molesini, S.; Ziosi, P.; Vaccaro, C.; et al. Comparative Study of SPA Mud from "Bacino Idrominerario Omogeneo dei Colli Euganei (B.I.O.C.E.)-Italy" and Industrially Optimized Mud for Skin Applications. Life 2020, 10, 78. [CrossRef] [PubMed]

41. Cui, X.; Li, S.; Xu, H.; Zhang, Z.; Zhao, X.; Gao, Z.; Wei, N.; Zhang, X. Late Quaternary Paleoenvironmental Reconstruction, Using Benthic Foraminifera and Ostracoda, of Marine Sedimentary Beds On the Southern Coast of Laizhou Bay, Bohai Sea, China. J. Foraminifer. Res. 2018, 48, 87-99. [CrossRef]

42. Scerri, S. Sedimentary Evolution and Resultant Geological Landscapes; Springer: Berlin, Germany, 2019; pp. 31-47.

43. Wagner, G.A. Age Determination of Young Rocks and Artifacts; Springer: Berlin, Germany, 1998. [CrossRef]

44. Park, J.Y.; Jang, M. Heterogeneous photooxidation of sulfur dioxide in the presence of airborne mineral dust particles. RSC Adv. 2016, 6, 58617-58627. [CrossRef]

45. Da Conceição, F.T.; Fernandes, A.M.; Hissler, C.; Lupinacci, C.M.; Menegário, A.A.; Moruzzi, R.B. Multi-tracer analysis to estimate the historical evolution of pollution in riverbed sediment of subtropical watershed, the lower course of the Piracicaba River, São Paulo, Brazil. Sci. Total. Environ. 2020, 743. [CrossRef]

46. Jablonska, M.; Rietmeijer, F.; Janeczek, J. Fine-grained barite in coal fly ash from the Upper Silesian Industrial Region. Environ. Geol. 2001, 40, 941-948. [CrossRef]

47. Wilczyńska-Michalik, W. Influence of Atmospheric Pollution on the Weathering of Stones in Cracow Monuments and Rock Outcrops in Cracow, Cracow-Częstochowa Upland and the Carpathians; Editor Wydawnictwo Naukowe Akademii Pedagogicznej: Krakow, Poland, 2004.

48. Toniolo, L.; Zerbi, C.M.; Bugini, R. Black layers on historical architecture. Environ. Sci. Pollut. Res. 2008, 16, 218-226. [CrossRef]

49. McAlister, J.J.; Smith, B.; Török, Á. Transition metals and water-soluble ions in deposits on a building and their potential catalysis of stone decay. Atmospheric Environ. 2008, 42, 7657-7668. [CrossRef]

50. Comite, V.; Ricca, M.; Ruffolo, S.A.; Graziano, S.F.; Rovella, N.; Rispoli, C.; Gallo, C.; Randazzo, L.; Barca, D.; Cappelletti, P.; et al. Multidisciplinary Approach for Evaluating the Geochemical Degradation of Building Stone Related to Pollution Sources in the Historical Center of Naples (Italy). Appl. Sci. 2020, 10, 4241. [CrossRef]

51. Bargossi, G.M.; Gamberini, F.; Gasparotto, G.; Grillini, G.C.; Marocchi, M. Dimension and Ornamental Stones from the Tosco-Romagnolo and Bolognese Apennine. Periodico di Mineralogia 2004, 73, 171-195.

52. Marszałek, M.; Alexandrowicz, Z.; Rzepa, G. Composition of weathering crusts on sandstones from natural outcrops and architectonic elements in an urban environment. Environ. Sci. Pollut. Res. 2014, 21, 14023-14036. [CrossRef] [PubMed]

53. Grossi, C.M.; Brimblecombe, P. The effect of atmospheric pollution on building materials. Le J. de Phys. Colloq. 2002, 12, 197-210. [CrossRef]

54. Martínez-Arkarazo, I.; Angulo, M.; Bartolomé, L.; Etxebarria, N.; Olazabal, M.Á.; Madariaga, J.M. An integrated analytical approach to diagnose the conservation state of building materials of a palace house in the metropolitan Bilbao (Basque Country, North of Spain). Anal. Chim. Acta 2007, 584, 350-359. [CrossRef]

55. Maurice, P. Environmental Surfaces and Interfaces from the Nanoscale to the Global Scale; Wiley: Hoboken, NJ, USA, 2009.

(C) 2020 by the authors. Licensee MDPI, Basel, Switzerland. This article is an open access article distributed under the terms and conditions of the Creative Commons Attribution (CC BY) license (http://creativecommons.org/licenses/by/4.0/). 